\title{
Agyagásvány nanoszerkezetek előállítása és fotokémiai aktivitásuk vizsgálata
}

\author{
HORVÁTH Erzsébet ${ }^{\mathrm{a}}$, KRISTÓF János ${ }^{\mathrm{a}^{*}}$, ZSIRKA Balázs ${ }^{\mathrm{a}}$ és VÁGVÖLGYI Veronika ${ }^{\mathrm{a}}$ \\ aPannon Egyetem, Analitikai Kémia Kutatócsoport, Egyetem u. 10, 8200, Veszprém, Magyarország
}

\section{Bevezetés}

A kaolinit és a halloysit a rétegszilikátok csoportjába tartozó agyagásványok, amelyeket az emberiség a civilizáció kezdete óta felhasznál. Kvázi fehér színük, kedvező fizikai és kémiai tulajdonságaik miatt jelenleg is igen fontos ipari nyersanyagok, nemcsak a kerámia-, hanem a papír-, festék-, müanyag-, gumi-, gyógyszer- és a kozmetikai iparban is. Felületük energetikai vagy sav-bázis tulajdonságainak módosításával a felhasználhatóság lehetőségei tovább bővíthetök ${ }^{1}$. Nemzetközi viszonylatban is nagy érdeklődés kíséri azokat a felületmódosító eljárásokat, amelyek agyagásvány alapú adszorbenseket és/vagy (foto)katalizátorokat kínálnak a környezeti ipar számára ${ }^{2}$. A Pannon Egyetem Analitikai Kémia Kutatócsoportjának legfontosabb alapkutatási eredményei a kaolinit és a halloysit szerkezetvizsgálatainak és felületmódosításainak területén születtek. A jelenlegi munkában azokat a kiemelt kutatási eredményeket kívánjuk bemutatni, amelyek a gyakorlati hasznosíthatóságot segítették.

\subsection{Kaolinit és halloysit szerkezete}

A kaolinit, valamint hidratált, polimorf módosulata, a halloysit a kaolinit-szerpentin csoportba tartozó 1:1 típusú rétegszilikát. A kaolinit szerkezetét egymáshoz kapcsolódó, $\mathrm{Si}^{4+}$ központú tetraéderes $(\mathrm{T})$ és $\mathrm{Al}^{3+}$ központú oktaéderes (O) egységekből felépülő rétegek alkotják. A központi $\mathrm{Si}^{4+}$ ionhoz tetraéderes elrendeződésben négy $\mathrm{O}^{2-}$ ion koordinálódik. A tetraéderek a síkban lévő 3 oxigénatomon keresztül kapcsolódnak egymáshoz és hatszögletes elrendezést alkotnak. A Si-tetraéder és az Al-oktaéder a csúcson lévő (ún. apikális) oxigénen keresztül kapcsolódik össze. Az $\mathrm{Al}^{3+}$ központú oktaéder-réteg szélein $\mathrm{O}^{2-}$ és $\mathrm{OH}^{-}$anionok helyezkednek el. A dioktaéderes szerkezet él menti kapcsolódással alkot hatszögletes elrendeződést. Az így kialakuló TO rétegeket hidrogénkötések kapcsolják egymáshoz, létrehozva a kaolinit tipikusan 7,2 $\AA$ bázislap távolsággal ismétlődő réteges szerkezetét (1. ábra). A kaolinitet jellegzetes, álhatszöges (pszeudo-hexagonális) morfológia jellemzi. A hidratált halloysitban a TO rétegek között vízmolekulák vannak (10 A), amely a nanotekercses morfológia kialakulását eredményezi.

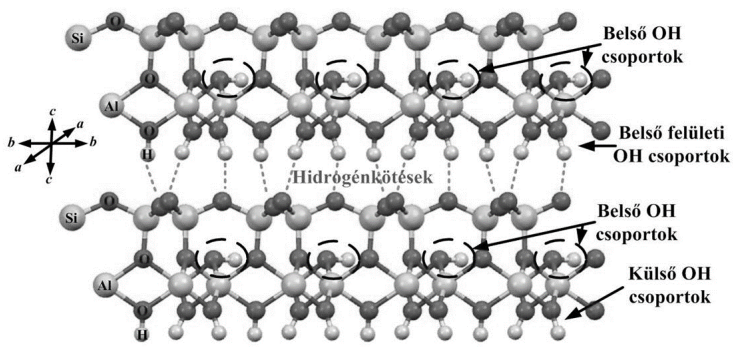

1. ábra. A kaolinit réteges szerkezete ${ }^{3}$

\subsection{Interkalációs technikák}

A kaolinit ásvány expandálhatóságának, interkalálhatóságának 1961-es leírása új távlatokat nyitott a felületmódosítás területén ${ }^{4,5}$. Az interkaláció során a kaolinit rétegközti terébe egy reaktív vendégmolekula lép be, felszakítja a meglévő hidrogénkötéseket és az expandált szerkezet létrejöttével egy új tulajdonságokkal rendelkező interkalációs komplex alakul ki (2. ábra).

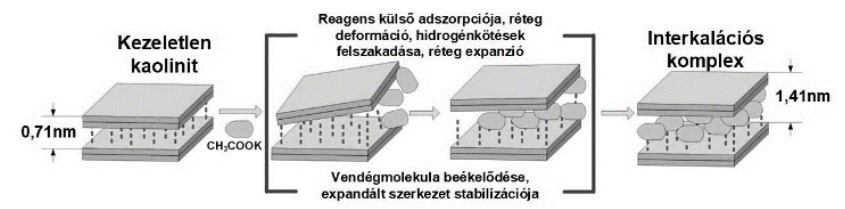

2. ábra. A kaolinit kálium-acetátos interkalációjának sematikus szemléltetése ${ }^{3}$

Kultúrtörténeti érdekesség, hogy a VI-VII. századi kínai porcelángyártás titka az volt, hogy a karbamid tartalmú állati vizelettel interkalált kaolinit rendkívül jó mechanikai tulajdonságokkal rendelkezett, amely a nagyon vékony falú (ún. tojáshéj) porcelán termékek előállítását tette lehetővé ${ }^{6}$. Vannak olyan elméletek, amelyek szerint szerves anyagokkal interkalált agyagásványok az élet kialakulásában is fontos szerepet játszhattak ${ }^{7}$. Az interkalációs komplexek szerkezetének megértése igen fontos a felületmódosító eljárások tervezhetősége szempontjából. Ennek előfeltétele volt a nagy teljesítményü nagymüszeres analitikai, például a termoanalitikai és a különböző spektroszkópiai módszerek elterjedése, valamint széleskörü hozzáférhetősége.

* Tel.: +36 88624000 / 6094; e-mail: kristof@almos.uni-pannon.hu 


\subsection{Interkalációs komplexek szerkezetvizsgálata}

A Kutatócsoport az 1990-es évektől foglalkozik kaolinok elsődleges interkalációs komplexeinek előállításával és szerkezetvizsgálatával.

Az interkalációs folyamatok vizsgálatának két aspektusa volt. Egyrészt az interkaláció, mint vizsgálati módszer a belső felület reaktivitására ad információt és ezen keresztül az agyagásványt is azonosítja. Másrészt, az interkaláció olyan felületmódosító eljárás, amellyel új (nano)kompozit anyagok illetve azok intermedierjei állíthatók elő. Az 1:1 típusú agyagásványok TO rétegkomplexumait nagyszámú hidrogénkötés tartja össze, interkalációra csak korlátozott számú vegyület használható. Az ilyen vegyületek tulajdonságai a következők szerint csoportosíthatók: (i) hidrogénkötésben proton donor és akceptor csoporttal rendelkezők, pl. hidrazin(-hidrát), formamid, karbamid; (ii) nagy dipólusmomentumú molekulák, pl. dimetil-szulfoxid (iii) rövid láncú zsírsavak bizonyos sói, pl. kálium-acetát. Az interkalálhatóság jelentős mértékben függ a kaolinit hidratáltságától, kristályszerkezeti rendezettségétől és ásványos szennyezőitől.

Az interkaláció hatására bekövetkező rétegközti expanzió röntgen-diffrakciós (XRD) technikával nyomon követhetö, de molekuláris szintủ szerkezeti információt a komplexek termoanalitikai és molekulaspektroszkópiai (IR, Raman) vizsgálataival kiegészítve nyerhetünk, amely kritikus fontosságú a későbbi csereinterkalációs felületmódosítások tervezéséhez.

Hidrazinnal interkalált kaolinit XRD felvételei többféle expandált szerkezet kialakulására utaltak. Ezek jelenlétét infravörös spektroszkópia alkalmazásával igazoltuk, továbbá megállapítottuk, hogy az expanzió mértéke függ a beépülő hidrazin molekulák orientációjától, illetve a hidratáltság fokától ${ }^{8}$. A többféle expandált szerkezetről még részletesebb képet a termoanalízis, azon belül is a nagy felbontású termoanalízis (CRTA) szolgáltathat ${ }^{9}, 10$. Ezzel a technikával a különböző energetikai szinten kötődő interkalált vendégmolekulák megkülönböztethetők és kvantitatív módon meghatározhatók. Ezzel a szerkezetben lévő belső felületi (hozzáférhető) hidroxilcsoportok számához viszonyított hidrazin esetleg hidrazin-hidrát mennyisége is kiszámítható. Ebből a szempontból a termoanalízis nem csak egy anyagvizsgáló módszer, hanem egy fontos eszköz annak érdekében, hogy tervezhető belső felületi tulajdonságokkal rendelkező interkalációs komplexet állíthassunk elő.

A különböző molekulaspektroszkópiai módszerekkel (MIR, NIR, FT-Raman) azonosítottuk az acetát-ion és a K-ion pozícióját, orientációját, és alátámasztottuk azt a feltételezést, amely szerint az interkalációs komplexben a belső felületi hidroxilcsoportok és a vízmolekulák között kölcsönhatás van, azaz az acetát ion vízmolekulán keresztül kapcsolódik a rétegközi térben a kaolinit hidroxilcsoportjaihoz ${ }^{11,12}$. A szerkezet azonosításából nyert tapasztalatok, különös tekintettel az interkalációs komplex stabilitását befolyásoló paraméterekre, kulcsfontosságúnak bizonyultak a későbbiekben, amikor kaolinit nanostruktúrák előállítását céloztuk meg.

\subsection{Delaminációs és exfoliációs technikák}

Az interkalált vegyület jellemzően reverzibilisen kötődik a rétegközti térben, ezért új interkalációs reagenssel, illetve reagensek sorozatával (ún. csereinterkalációval) lecserélhető. Következésképpen olyan vegyületek is a rétegközti térbe juttathatók, amelyek egy lépésben, közvetlenül nem interkalálhatók. A többlépéses csereinterkaláció során megygyengülnek a rétegeket összetartó hidrogénkötések, így az eredeti morfológia megváltozásával a TO rétegek széteshetnek (3. ábra). A rétegeket összetartó hidrogénkötések jelentős meggyengülése felerősíti a $\mathrm{T}$ és $\mathrm{O}$ rétegsíkok közti méretkülönbségek hatását, amely a TO réteg felcsavarodását eredményezi és belül üreges, tekercses nanostruktúrák alakulnak ki.

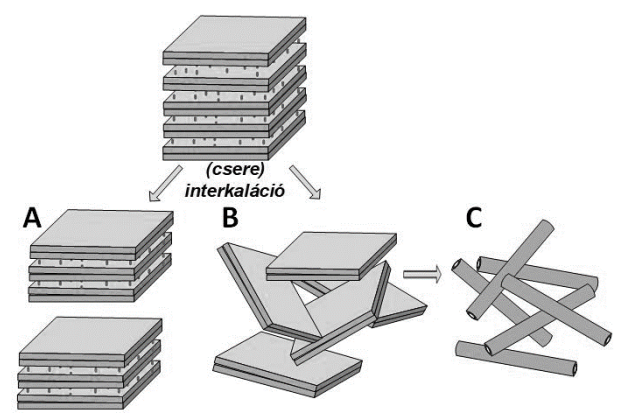

3. ábra. Morfológiai változások sematikus szemléltetése (A: delamináció, B: exfoliáció, C: nanotekercs felcsavarodás) ${ }^{3}$

A kaolinit exfoliációjára több csereinterkalációs lépést is kidolgoztunk ${ }^{13}$. A kaolinit-karbamid (U) interkalációs komplex együtt örlésével az XRD felvételek alapján (4/A. ábra) közel 100\%-os interkalációs hatásfok érhető el, ami trietanol-aminnal (TEA) majd metil-jodiddal (MeI) azonos hatásfokkal lecserélhető. A kaolinit rétegközti terében létrehozott kvaterner-ammónium-só nátrium-poliakriláttal (PANa) interkalálható majd mosást követően $100 \%$-os hatásfokkal exfoliálható.
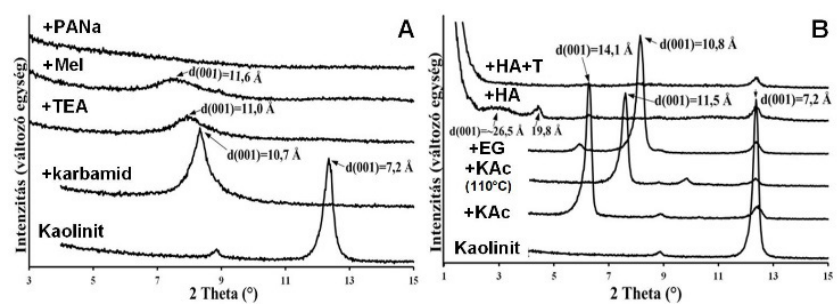

4. ábra. A csereinterkaláció folyamatának XRD felvételei két különböző szintézisút esetén (A: karbamid/trietanol-amin(TEA)/metil-jodid(MeI)/ nátrium-poliakrilát(PANa), B: kálium-acetát(KAc)/etilén-glikol(EG)/ hexil-amin(HA)/toluol(T) $)^{3,13}$

Az exfoliációt a d(001) reflexió eltűnése jelzi. A PANa reagens a nanostruktúrák felületéhez erősen kötődik, ami speciális alkalmazásnál (pl. polimer adalékanyag) igen kedvező 
lehet. Ugyanakkor az őrlés amorfizációt okoz, ezért a tekercses morfológia kialakulása szempontjából kedvezőtlen.

A másik esetben kálium-acetát reagenssel (KAc) interkalált prekurzort állítunk elő, amely hőkezelés hatására destabilizálható és ezt követően etilén-glikollal (EG), majd hexil-aminnal (HA) lecserélhető. A rétegek exfoliációját a toluolos mosás biztosítja. A kaolinit eredeti, expandálatlan d(001) reflexiójának megléte jelzi az alacsonyabb, kb. 93\%os, átlagos interkalációs és exfoliációs hatékonyságot. Az exfoliált kaolinit nanostruktúrák felületi hidroxilcsoportjai hozzáférhetőek maradnak és jellemzően nanotekercses morfológiával rendelkeznek (5. ábra). A kaolinitre kidolgozott exfoliációs módszer (a természetes állapotában is nanotekercses morfológiájú) hidratált halloysitra is alkalmazható ${ }^{14}$, így az eredetinél vékonyabb és homogénebb eloszlást mutató nanotekercsek állíthatók elö (6/A. ábra).

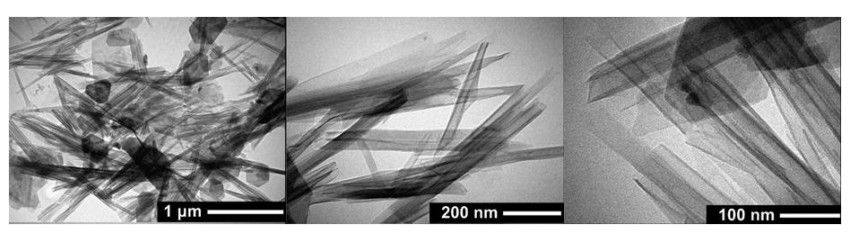

5. ábra. Az exfoliált kaolinit nanostruktúra tekercses morfológiája $(\mathrm{TEM})^{3,13}$

\subsection{Szerkezeti hibahelyek kialakítása (savas-, termikus-, mechanokémiai kezelés)}

Az ipari nyersanyagok felhasználását jellemzően felületiés szerkezeti tulajdonságaik határozzák meg. Az agyagásványok fizikai és kémiai tulajdonságainak módosítására, az előző fejezetben bemutatott interkaláció mellett, leggyakrabban a mechanokémiai aktiváció (őrlés), a termikus és a savas kezelés használatos. A szerkezeti hibahelyek, mint katalitikusan aktív centrumok, jelentősen javíthatják a katalitikus aktivitást.

Az exfoliált nanohalloysit szerkezetében örléssel kialakított hibahelyek a felület savas karakterét növelik ugyan, de a szerkezet amorfizációja (6/B. ábra), a fajlagos felület és a pórustérfogat csökkenése katalitikus szempontból kedvezőtlen ${ }^{15}$.

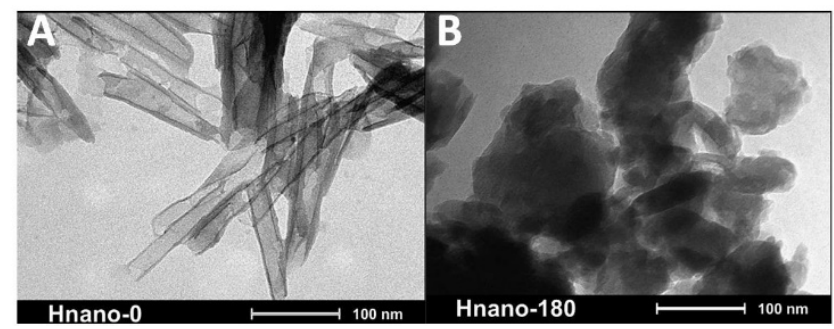

6. ábra. Az exfoliált nanohalloysit tekercses morfológiája; A: exfoliáció után, őrlés előtt, B: annak amorfizációja 180 perces őrlés hatására $(\mathrm{TEM})^{3,15}$
Ezzel szemben a termikus kezeléssel kíméletesebben, az amorfizáció elkerülésével hozhatók létre szerkezeti hibahelyek. A kaolinit szerkezetében kb. 360-600 ${ }^{\circ} \mathrm{C}$ hőmérsékleti tartományban az Al-oktaéderen lévő szerkezeti hidroxilcsoportok dehidroxilációja megy végbe, amely csökkent koordinációjú Al-hibahelyeket $\left({ }^{\mathrm{V}} \mathrm{Al}\right.$, $\left.{ }^{\mathrm{IV}} \mathrm{Al}\right)$ eredményez. A szerkezeti hibahelyek ${ }^{27} \mathrm{Al}$ MAS NMR spektroszkópiai módszerrel azonosíthatók (7. ábra), populációjuk a hőkezelés hőmérsékletétől és a kezelés idejétől függ. A hibahelyek felületi tulajdonságokra gyakorolt hatását kísérleti és elméleti számítási módszerekkel (DFT) is tanulmányoztuk ${ }^{16-18}$. A hőkezelés paramétereinek megfelelő megválasztásával a visszamaradt hidroxilcsoportok mennyisége, valamint a hibahelyek mennyisége is szabályozható. Ezzel a katalitikus szempontból előnyös pórusméret (diffúziós gátlás csökkentése) és a fajlagos felület (reakciófelület) is biztosítható ${ }^{18}$.

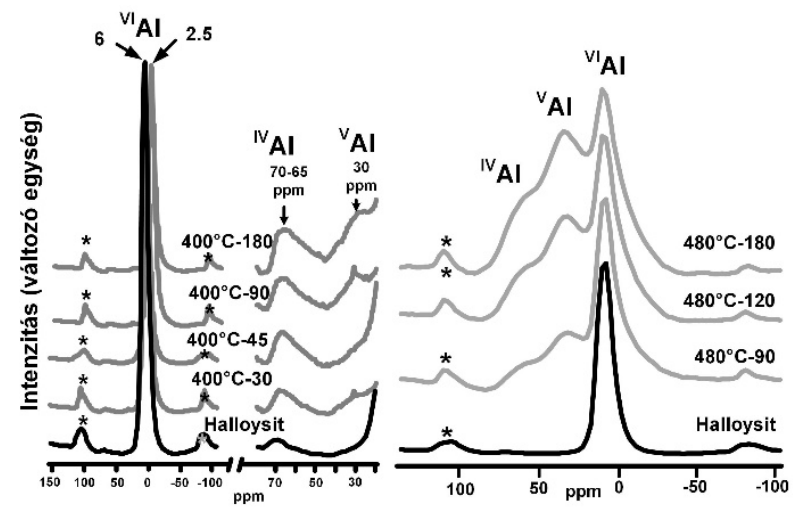

7. ábra. Csökkent koordinációjú ( $\left.{ }^{\mathrm{V}} \mathrm{Al},{ }^{\mathrm{IV}} \mathrm{Al}\right)$ szerkezeti hibahelyek kialakítása halloysitban $\left({ }^{27} \mathrm{Al} \text { MAS NMR }\right)^{18}$

Katalitikus szempontból rendkívül érdekesek azok a kaolinok, amelyek fotokémiai aktivitással rendelkező szennyezéseket is tartalmaznak. A rutil/anatáz, goethit vagy hematit szennyezők jelentősen befolyásolhatják a szerkezeti- és a felületi tulajdonságokat. Savazással nem csak a felületi tulajdonságok módosíthatók, hanem a sav-oldható szenynyezők felületi koncentrációja és/vagy morfológiája is megváltozható, amely a felület termodinamikai tulajdonságait jelentősen befolyásolhatja. Az ásványosan és szerkezetében vassal szennyezett kaolin sósavas kezelésével az aluminoszilikát váz alapvetően nem roncsolódik, de a szerkezeti hidroxilcsoportok kismértékü protonálódása bekövetkezik $^{18,19}$. Ez azt jelenti, hogy az oktaéderes réteg felületén a protonált $\mathrm{OH}$, mint koordinációs víz jelenléte koordinatíve telítetlen penta- és tetraéderes Al-centrumokat eredményez. A sav koncentrációjának és a savazás idejének függvényében a vastartalmú ásványos szennyezések $\left(\mathrm{Fe}_{2} \mathrm{O}_{3}, \mathrm{FeOOH}\right)$ felületi koncentrációja optimalizálható, a katalitikus aktivitás maximalizálható.

\section{Fotokémiai reakciók szilárd és folyadék fázisban}

Az agyagásvány irodalom a kaolinit fotokémiai aktivitását az aluminoszilikát kristályszerkezetnek tulajdonítja ${ }^{20}$. A nátrium-benzolszulfonát (BS) tesztvegyület UV bevilágí- 
tás $\left(\lambda_{\max }=365 \mathrm{~nm}, 254 \mathrm{~nm}\right)$ hatására bekövetkező bomlását mi is tapasztaltuk ezüsttel felületmódosított exfoliált kaolinit nanostruktúrák jelenlétében ${ }^{21}$. A bomlási folyamat infravörös spektroszkópiai (FTIR-ATR) módszerrel nyomon követhető. Az FT-IR spektrumok tanúsága szerint az aromás gyürü felnyílásával és az azt követő deszulfonizációval megy végbe a tesztvegyület (részleges) bomlása (8. ábra).

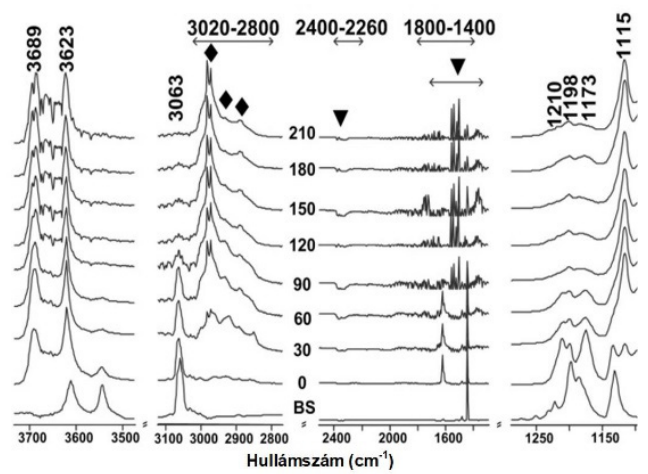

8. ábra. Nátrium-benzolszulfonát tesztvegyület bomlásának folyamata 365 nm-es UV fénnyel bevilágított ezüsttel módosított exfoliált kaolinit nanostruktúrák felületén (FTIR-ATR spektrumok) ${ }^{3,21}$

A későbbiek során a fotokatalitikus aktivitás számszerüsítésére az egyszerü folyamatban mineralizálódó oxálsavat használtuk tesztvegyületként, vizes oldatban. Kezeletlen kaolinok és halloysitok jelenlétében a tesztvegyület változó mértékü (kb. 5-90\%) fotokémiai bomlását tapasztaltuk (9. ábra). A reakciófelület és az ásványos szennyezések mellett a szerkezeti hibahelyek mennyisége határozottan befolyásolja a bontási hatásfokot. Tekintettel azonban arra, hogy az ásványos és/vagy strukturális szennyezők, valamint a hibahelyek jelenléte a felület Brønsted és Lewis savas tulajdonságait jelentősen befolyásolják, nagyon fontos tisztázni a fotokatalitikus folyamat mechanizmusát. Mivel a kaolinok felülete energetikai szempontból rendkívül heterogén, feltételezésünk szerint a Brønsted és a Lewis kötőhelyek aránya befolyásolhatja a katalitikus hatásfokot és annak szórását.

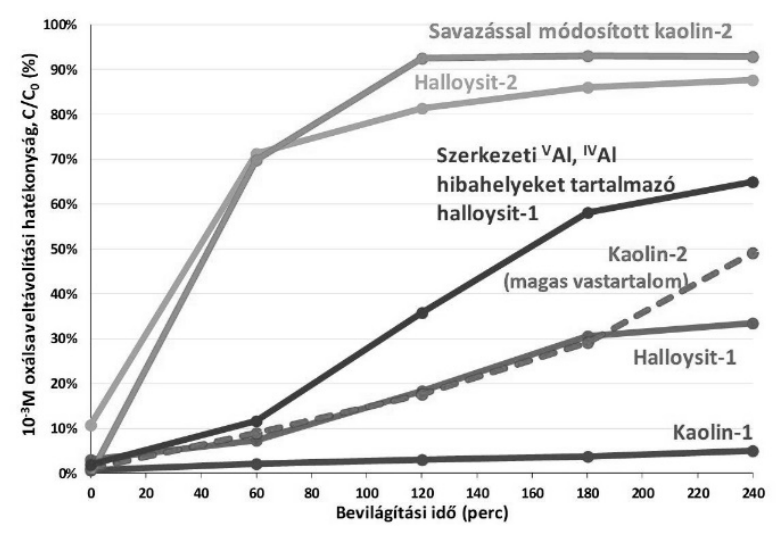

9. ábra. Kezeletlen kaolinok és halloysitok valamint felületmódosított változataik 365 nm-es UV fényü bevilágítása során megfigyelt folyadékfázisú oxálsav tesztvegyület $\left(10^{-3} \mathrm{M}\right.$, vizes oldat) fotokatalitikus eltávolításának hatékonyságai ${ }^{18,19,22}$
Mivel az agyagásványok fotokatalitikus aktivitásának fizikai-kémiai háttere még nem tisztázott, így az egyes szenynyezők bontására közölt adatok inkább empirikus megfigyeléseknek tekinthetők. Az irodalom azzal az alapvető feltételezéssel él, hogy a fotokatalitikus aktivitás a félvezető fotokatalizátorokhoz hasonlóan magyarázható, vagyis megfelelő energiájú foton besugárzás hatására a fotoindukált elektron-lyuk párok és a képződő reaktív gyökök jelenléte okozza a célanyag bomlását. A kumarin gyökbefogóval végzett kísérleteink azonban ezt a feltételezést nem erősítik meg. A bevilágítás hatására keletkező reaktív $\bullet \mathrm{OH}$ mennyisége rendkívül alacsony volt, ami nem magyarázza a jelentős mértékű oxálsav eltávolítást. Ez a megfigyelés inkább egy másik fotokémiai mechanizmus, a fényérzékeny oxaláto-komplex felületi kialakulásának lehetőségét veti fel (10. ábra $)^{18}$. Következésképpen a kaolinok, különösen a természetes, ásványosan és/vagy strukturálisan szennyezett kaolinok fotokatalizátorként való alkalmazhatósága a felület termodinamikai jellemzését és a felületi komplexképződést befolyásoló paraméterek szisztematikus feltárását igényli, amely a jövőben megoldandó kutatási feladat.

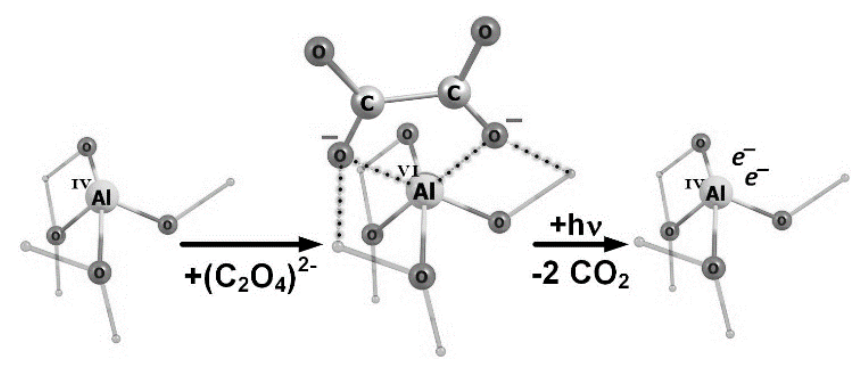

10. ábra. Koordinatíve telítetlen, felületi ${ }^{\mathrm{IV}} \mathrm{Al}$ szerkezeti hibahelyhez koordinálódó fényérzékeny oxalát bomlás sematikus szemléltetése ${ }^{18}$

\section{7. Összefoglalás}

A környezeti elemek védelme és a szennyezöktől való megtisztítása robusztus, könnyen és nagy mennyiségben hozzáférhető, természet azonos nyersanyagokat igényel. Az agyagásványok változatos szerkezetủ és széleskörben hozzáférhető természetes anyagok. Felhasználhatóságuk a felületi reaktivitásuk függvénye. Mivel a felületük energetikai szempontból heterogén, a felületi tulajdonságok feltárása és jellemzése alapvető az adott feladatra legalkalmasabb felület megtervezésének érdekében.

\section{Köszönetnyilvánítás}

A kutatási témát a Pannon Egyetem Mérnöki Karának vezetése kiemelt kutatási projektként kezelte, mind a hazai, mind a nemzetközi pályázatokban való részvételét támogatta és segítette. A szerzők ezúton is megköszönik a Mérnöki Kar támogatását. 


\section{Hivatkozások}

1. Murray, H. H. Kaolin Applications (5. Fejezet). In Developments in Clay Science 2 Applied Clay Mineralogy: Occurrences, Processing and Application of Kaolins, Bentonites, Palygorskite-Sepiolite, and Common Clays; Murray, H. H., Ed.; Elsevier Science, 2006; pp 85-110. https://doi.org/10.1016/S1572-4352(06)02005-8

2. Guan, H.; Zhao, Y. 9 - Decontamination Application of Nanoclays. In Micro and Nano Technologies; Cavallaro, G., Fakhrullin, R., Pasbakhsh, P. B. T.-C. N., Eds.; Elsevier, 2020; pp 203-224. https://doi.org/10.1016/B978-0-12-816783-0.00009-8

3. Zsirka Balázs. Kaolinit-Csoportba Tartozó Agyagásványok Nanostruktúráinak Előállítása, Szerkezeti És Felületi Jellemzésük $=$ Synthesis, Structural and Surface Characterization of Clay Nanostructures Belonging to the Kaolin Group Minerals., University of Pannonia, 2018. https://doi.org/10.18136/PE.2017.669

4. Weiss, A. Eine SchichteinschluXverbindung von Kaolinit Mit Harnstoff. Angew. Chemie 1961, 73, 736-737. https://doi.org/10.1002/ange.19610732205

5. Wada, K. Lattice Expansion of Kaolin Minerals by Treatment with Potassium Acetate. Am. Mineral. 1961, 46, 78-91.

6. Weiss, A. A Secret of Chinese Porcelain Manufacture. Angew. Chemie Int. Ed. English 1963, 2 (12), 697-703. https://doi.org/10.1002/anie.196306971

7. Brack, A. Clay Minerals and the Origin of Life. In Developments in Clay Science; Faïza Bergaya, G. L., Ed.; 2013; pp 507-521. https://doi.org/10.1016/B978-0-08-098258-8.00016-X

8. Frost, R. L.; Kristof, J.; Paroz, G. N.; Kloprogge, J. T. Role of Water in the Intercalation of Kaolinite with Hydrazine. $J$. Colloid Interface Sci. 1998, 208 (1), 216-225. https://doi.org/10.1006/jcis.1998.5780

9. Horváth, E.; Kristóf, J.; Frost, R. L.; Rédey, Á.; Vágvölgyi, V.; Cseh, T. Hydrazine-Hydrate Intercalated Halloysite under Controlled-Rate Thermal Analysis Conditions. $J$. Therm. Anal. Calorim. 2003, 71 (3), 707-714. https://doi.org/10.1023/A:1023301504396

10. Kristóf, J.; Frost, R. L.; Martens, W. N.; Horváth, E. Separation of Adsorbed and Intercalated Hydrazine in Hydrazine-Hydrate Intercalated Kaolinite by ControlledRate Thermal Analysis. Langmuir 2002, 18 (4), 1244-1249. https://doi.org/10.1021/la011179

11. Frost, R. L.; Thu Ha, T.; Kristof, J. FT-Raman Spectroscopy of the Lattice Region of Kaolinite and Its Intercalates. Vib. Spectrosc. 1997, 13 (2), 175-186. https://doi.org/10.1016/S0924-2031(96)00049-5

12. Frost, R. L.; Locos, O. B.; Kristof, J.; Kloprogge, J. T. Infrared Spectroscopic Study of Potassium and Cesium Acetate-Intercalated Kaolinites. Vib. Spectrosc. 2001, 26 (1), $33-42$.

https://doi.org/10.1016/S0924-2031(01)00108-4
13. Zsirka, B.; Horváth, E.; Makó, É.; Kurdi, R.; Kristóf, J. Preparation and Characterization of Kaolinite Nanostructures: Reaction Pathways, Morphology and Structural Order. Clay Miner. 2015, 50 (3), 329-340. https://doi.org/10.1180/claymin.2015.050.3.06

14. Zsirka, B.; Horváth, E.; Szabó, P.; Juzsakova, T.; Szilágyi, R. K.; Fertig, D.; Makó, É.; Varga, T.; Kónya, Z.; Kukovecz, Á.; Kristóf, J. Thin-Walled Nanoscrolls by Multi-Step Intercalation from Tubular Halloysite-10 $\AA$ and Its Rearrangement upon Peroxide Treatment. Appl. Surf. Sci. 2017, 399. https://doi.org/10.1016/j.apsusc.2016.12.053

15. Zsirka, B.; Táborosi, A.; Szabó, P.; Szilágyi, R. K.; Horváth, E.; Juzsakova, T.; Fertig, D.; Kristóf, J. Surface Characterization of Mechanochemically Modified Exfoliated Halloysite Nanoscrolls. Langmuir 2017, 33 (14), 3534-3547. https://doi.org/10.1021/acs.langmuir.6b04606

16. Táborosi, A.; Szilagyi, R. K.; Zsirka, B.; Fónagy, O.; Horváth, E.; Kristóf, J. Molecular Treatment of NanoKaolinite Generations. Inorg. Chem. 2018, 57 (12). https://doi.org/10.1021/acs.inorgchem.8b00877

17. Vágvölgyi, V.; Győrfi, K.; Zsirka, B.; Horváth, E.; Kristóf, J. The Role of Thermal Analysis in the Development of High-Iron-Content Kaolinite-Based Photocatalysts. J. Therm. Anal. Calorim. 2020, 142 (1). https://doi.org/10.1007/s10973-020-09350-2

18. Zsirka, B.; Vágvölgyi, V.; Győrfi, K.; Horváth, E.; Szilágyi, R. K.; Szabó-Bárdos, E.; Balogh, S.; Kristóf, J. Compositional, Structural, and Surface Characterization of Heat-Treated Halloysite Samples: Influence of Surface Treatment on Photochemical Activity. Appl. Clay Sci. 2021, $212,106222$. https://doi.org/10.1016/j.clay.2021.106222

19. Győrfi, K.; Vágvölgyi, V.; Zsirka, B.; Horváth, E.; Szilágyi, R. K.; Baán, K.; Balogh, S.; Kristóf, J. Kaolins of High Iron-Content as Photocatalysts: Challenges of Acidic Surface Modifications and Mechanistic Insights. Appl. Clay Sci. 2020, 195, 105722. https://doi.org/10.1016/j.clay.2020.105722

20. Kibanova, D.; Trejo, M.; Destaillats, H.; Cervini-Silva, J. Photocatalytic Activity of Kaolinite. Catal. Commun. 2011, 12 (8), 698-702. https://doi.org/10.1016/j.catcom.2010.10.029

21. Szabó, P.; Zsirka, B.; Fertig, D.; Horváth, E.; Csizmadia, T.; Kristóf, J. Delaminated Kaolinites as Potential Photocatalysts: Tracking Degradation of NaBenzenesulfonate Test Compound Adsorbed on the Dry Surface of Kaolinite Nanostructures. Catal. Today 2017, 287. https://doi.org/10.1016/j.cattod.2017.01.051

22. Vágvölgyi, V.; Győrfi, K.; Zsirka, B.; Horváth, E.; Kristóf, J. The Role of Thermal Analysis in the Development of High-Iron-Content Kaolinite-Based Photocatalysts. $J$. Therm. Anal. Calorim. 2020, 142 (1), 289-299. https://doi.org/10.1007/s10973-020-09350-2 


\section{Synthesis of clay nanostructures and assessment of their photocatalytic activity}

Clay minerals as cheap, abundant raw materials are widely used in various fields of industry due to their favourable physical and chemical properties. With the use of various surface modification techniques (e.g. mechanochemical activation, heat- and acidtreatment) their potential field of use can be significantly extended. There is an increasing interest in environmental remediation technologies to utilize efficient, cheap and environment-friendly catalysts, where natural clay minerals offer good alternatives as adsorbents, catalyst supports or co-catalysts. Kaolinite and its hydrated polymorph, halloysite are 1:1 type layered aluminosilicates. Their structure consists of a two-dimensional arrangement of an $\mathrm{Al}^{3+}$-centered octahedral (O) and also a two-dimensional arrangement of a $\mathrm{Si}^{4+}$-centered tetrahedral sheet. These double layers are held together by hydrogen bonds. The hydrogen-bonds can be broken up by e.g. short-chain fatty acids and the layers can be expanded. This process is called intercalation.

The most important findings of our fundamental research related to the structural characterization and surface modification of clay minerals are summarized in the present work. The structure elucidation of intercalation complexes with reagent molecules as potassium acetate, hydrazine, dimethyl sulfoxide and urea was carried out by the use of highly sophisticated instrumental techniques (HT-XRD, FTIR, FT-Raman, ${ }^{27} \mathrm{Al}$ NMR, TPD and thermal analysis). The structural models set up by us are accepted and widely used by clay scientists. Understanding the structure of the intercalation complexes enabled us to develop novel layer-expansion technics (multi-step or cascade intercalation) to further expand the double layers to completely delaminate the minerals. With the use of new synthesis routes, exfoliated kaolinite and halloysite nanostructures with scroll-like morphology were obtained. The effects of mechanochemical activation (grinding), thermaland acid treatments were investigated in order to modify surface properties and enhance reactivity via the introduction of various structural defect sites.

The most significant result of this research is the discovery of the photocatalytic activity of exfoliated kaolinite and halloysite and their surface-modified derivatives. The photochemical behaviour of nanokaolinite was investigated in the solid phase with the use of Na-benzenesulfonate test compound with FTIR-ATR method upon irradiation with 254 and $365 \mathrm{~nm}$ UV light. The decomposition process was significantly faster after the deposition of $\mathrm{Ag}$ nanoparticles onto the mineral surface. Independently of the type of the starting mineral and the experimental conditions, the decomposition products were $\mathrm{Na}_{2} \mathrm{SO}_{4}, \mathrm{H}_{2} \mathrm{O}$ and $\mathrm{CO}_{2}$.

It was observed that defect sites induced by thermal- or acid treatment can significantly increase catalytic activity. As identified by ${ }^{27} \mathrm{Al}$ NMR spectroscopy, V- and IV-fold Al-coordination (leading to coordinatively unsaturated active sites) is responsible for the increased catalytic activity. As to the acid-treated nanoclays, Brønsted acid sites as well as basic centers were identified by TPD measurements (using $\mathrm{NH}_{3}$ and $\mathrm{CO}_{2}$ test gases). In addition, Lewis acid sites were identified as well by inverse gas chromatography.

The catalytic activity of the acid-treated nanoclays was investigated in the solution phase using oxalic acid test compound. It was found that in addition to the type of the reaction surface and the nature of the (e.g. iron-bearing) mineral contaminants, the number of defect sites and the Brøndted and Lewis acid centers can significantly influence the photochemical activity.

Since the physico-chemical background of the photochemical activity of clay minerals is unclear, the data published on the decomposition of various organic contaminants in water are based on empirical observations. Several authors suggest that the photochemical activity is due to a mechanism similar to that of semiconductor type catalysts (e.g. $\mathrm{TiO}_{2}$ ), through the formation of electron-hole pairs, but the coumarin tests do not support this supposition. The amount of reactive $\bullet \mathrm{OH}$ radicals for oxalic acid decomposition was extremely low, unsuitable for the complete mineralization of the test compound. In our approach the close to $100 \%$ decomposition rate can be explained by the formation of a photosensitive oxalate complex with the IV-coordinated Al-sites.

For the efficient use of clay-based photocatalysts further research and an in-depth understanding of the photochemical mechanism (and its correlation to the surface properties) is required. 